\title{
Bipartite Industrial Relations Settlement Assistance to Reduce Disputes Between Garment Company Workers and Entrepreneurs in Malang Regency
}

\author{
Fullchis Nurtjahjani*, Joni Dwi Pribadi, Masreviastuti, Sanita Dhakira, Ane Fany Novitasari \\ Lecturer in General Courses \\ State of Polytechnic of Malang \\ Malang, Indonesia \\ *fullnurtjahjani@gmail.com
}

\begin{abstract}
This study discusses the settlement of disputes between workers and employers of Garment Companies in Malang City. The purpose of this study is to analyze the bipartite settlement of industrial relations. This research is a descriptive study using a qualitative approach. Primary data were obtained through interviews with representatives of PT Dwi Putra Sakti and representatives of the Malang Regency Manpower Office. During the bipartite negotiation activity, all parties accepted the predetermined decisions. settlement of disputes that occur in accordance with legislation.
\end{abstract}

Keywords - industrial relations, bipartite, disputes

\section{INTRODUCTION}

Disputes between workers and employers in an employment relationship are a natural thing to happen. However, if a dispute cannot be resolved, it will have a bad impact not only on the parties, but also indirectly on the Indonesian economy. Especially during times of crisis, among others, demonstrations, strikes and layoffs occur, all of which can occur due to unsolvable disputes between the two parties.

The parties, workers and employers need to maintain a working relationship. A peaceful mechanism is needed to resolve disputes between them, because the parties have a high stake in their relationship. On the one hand, entrepreneurs as businessmen want to get as much profit as possible from their business.

On the other hand, workers want the highest wage from the work done to pay for their daily needs. These different interests often put the parties in different positions and put them in conflicting conditions. Thus, workers and employers need a dispute resolution mechanism that can resolve their disputes without ending their working relationship.

In the current era of globalization, it must be admitted that workers/laborers who work in companies or anywhere as long as workers/laborers do work relations are based on work agreements, it turns out that there are still many who do not understand and even become confused when disputes or differences of opinion occur with the employer or employer at the workplace.

PT Dwi Sakti Putera is a company engaged in the garment sector in Malang Regency, there are several problems faced by the company and its employees, including the following:

- Workers complain that the rights that should be obtained have not been fulfilled by employers

- Workers complain about late payment of salaries

- Work strikes carried out by workers due to unilateral cuts in benefits by the company

- Failure of production targets imposed on workers

By paying attention to the problems faced by the partners and referring to the results of the agreement between the proposer and the partner, the priority problems are as follows: The existence of disputes between workers which include disputes over rights, disputes over interests, disputes over termination of employment, and disputes between trade unions / labor unions in only one company.

The occurrence of this dispute will certainly disturb and affect the balance of the human order in society, so that humans always try to create a balance in order to create an orderly, peaceful and safe atmosphere which is a guarantee of their survival. The balance of the human order in a disturbed society must be restored to its original state. Disputes that occur also have an impact on company operations and have an impact on the obstruction of the production process, so it is necessary to establish a model for settling industrial relations disputes regulated by law that can accommodate the resolution of all forms of disputes industrial relations. According to Candra [1] states that the issuance of Law Number 2 of 2004 [2] concerning the Settlement of Industrial Relations Disputes is an answer to differences of opinion that have resulted in conflicts between workers and employers, due to disputes over rights, disputes over interests, disputes over termination of 
employment, and disputes between unions. workers/labor unions in one company. Based on the background described above, the researcher is interested in discussing the research with the title "Assistance for Bipartite Industrial Relations Settlement to Reduce Disputes between Workers and Garment Company Entrepreneurs in Malang Regency".

\section{METHODS}

This research is a descriptive study using a qualitative approach. This research was conducted at PT Dwi Putra Sakti which is located at Jalan Raya Pakis jajar No. 8 Malang, East Java and Malang Regency Manpower Office. This study uses primary data and secondary data. Primary data comes from interviews with representatives of PT Dwi Sakti Putera and representatives of the Malang Regency Manpower Office. Secondary data in this study are in the form of laws and regulations relating to the problems examined by the authors.

\section{DISCUSSION}

\section{A. Types of Industrial Relations Disputes between Garment Workers and Entrepreneurs in Malang City}

Khakim [3] states that by nature disputes are divided into two types, namely 1) collective labor disputes, namely labor that occurs between employers and Workers' Unions (SP), because there is no concurrent understanding of work relations, work conditions or labor conditions (employment) 2) individual labor disputes, namely disputes between workers or laborers who are not members of a workers' union (SP) or labor union (SB) and an entrepreneur.

Industrial relations disputes that occur in Malang City Garment companies are included in collective labor disputes, because there is no adjustment of understanding regarding work relations or labor conditions where unstable industrial conditions cause industrial relations disputes to occur. For example, regarding late payment of salaries, cutting benefits and failure of production targets imposed on employees. The garment company was forced to carry out this policy because the company's finances were disrupted, so they cut these allowances.

On the one hand, workers as subjects who are directly related to the production process in carrying out the duties of the company often make mistakes. On the other hand, they demand a decent income and more than enough, adequate facilities from companies such as food and transportation allowances. The causes of industrial disputes according to the company are:

- Not disciplined in the production process activities

- Do not understand the contents of company regulations and work agreements.

These causes have an impact on the achievement of production and company income. This is what causes the Garment Company to be late in paying salaries and benefits. educate the causes of industrial relations disputes according to the workers are:

- Paying late

- A burdensome task

- Deductions in allowances

\section{B. Settlement of Industrial Relations Disputes between Workers and Garment Entrepreneurs in Malang City}

Efforts are made to resolve disputes between Gamen workers and entrepreneurs so that each party is not harmed. Basically, every industrial relations dispute must be settled on a bipartite basis before reaching the level of the Industria Relations Court. The parties in this bipartite consist of representatives of employers and representatives of workers and / or trade unions.

If the company has not yet formed a union, workers' representatives in the bipartite are elected to represent work units and / or professional groups. If there is more than one trade union, their representatives in the bipartite are appointed proportionally. The agreement or compromise reached in bipartite is formulated in the form of a mutual agreement signed by the disputing parties. If one party does not implement the collective agreement, the injured party can submit a request for a decision to be executed to the Industrial Relations Court at the local District Court, although it is not specifically regulated in law, the workers' unions in the company can form a communication forum between the trade unions.

Negotiation is an effort made through discussion, persuasive action / persuasion, and compromise to reach an agreement with another party regarding a particular problem or a process in which two or more parties have the same interest (common interest) or conflicting (conflicting). interest) meet and talk with an intention to reach a mutually agreed agreement. That this also refers to the provisions of Article 3 paragraph (1) Law No. 2 of 2004 [2] Regarding the Settlement of Industrial Relations Disputes (PPHI) it has been stipulated that the settlement of industrial relations disputes (labor disputes) must be pursued first through Bipartite negotiations by deliberation to reach a consensus.

In the Bipartite negotiation settlement process, it is necessary to prepare a summary of the results of the negotiations as referred to in Article 6 paragraph 2 UU no. 13 of 2003 about Manpower must contain at least [4]:

- Full names and addresses of the parties

- The date and place of the negotiations

- The subject matter or reason for the dispute

- Opinions of the parties

- Conclusions or results of negotiations, and

- Date and signatures of the parties conducting the negotiations 
As for the bipartite negotiation procedure for workers / laborers and employers in the event of an Industrial Relations dispute (labor dispute), with reference to Law No. 2 of 2004 is as follows [2]:

- The bipartite settlement must be completed no later than 30 days from the commencement of negotiations (article 3 paragraph 2);

- If the bipartite negotiation effort reaches an agreement, a collective agreement is signed by the parties (article 7 paragraph 1);

- The collective agreement must be registered by the parties who entered into the agreement at the Industrial Relations Court at the District Court in the territory of the parties to enter into a collective agreement (article 7 paragraph 3);

- The collective agreement that has been registered is given a deed of proof of collective agreement registration and is an inseparable part of the collective agreement (article 7 paragraph 4);

- If the collective agreement that has been registered is not carried out by one of the parties, the aggrieved party may submit a request for execution to the Industrial Relations Court at the District Court in the area of the collective agreement registered for the decision of execution (article 7 paragraph 5)

- If within 30 working days one of the parties refuses to negotiate or has conducted negotiations, but does not reach an agreement, the bipartite negotiation is deemed a failure (article 3 paragraph 3 );

- If the bipartite negotiation effort fails, one of the parties or both parties will register the dispute with the local manpower agency by attaching evidence that the bipartite effort has been carried out (article 4 paragraph $1)$;

- If the evidence is not attached, the agency responsible for the local manpower sector should return the files to be completed at the latest within (seven) working days from the date of return of the files (article 4 paragraph 2).

- In every bipartite negotiation, a treatise must be made and signed by the parties (article 6 paragraph 2)

- Collective agreement (PB) must be registered by the parties who enter into an agreement with the industrial relations court to obtain a proof of registration deed (Article 7 paragraphs 3 and 4)

Negotiations do not always reach an agreement, if a deliberative settlement for consensus cannot be reached, the entrepreneur and / or worker / SP will then register the dispute with the local manpower agency by attaching evidence that the settlement effort through bipartite negotiation has been carried out. If the proof is not attached, the manpower agency will return the documents to be completed no later than seven working days from the date of receipt of the returned files After receiving the records of one or the parties, the local employment agency, is obliged to offer the parties to agree to choose a settlement through arbitration (for disputes over interests and between unions within one company), or through conciliation (for dismissal disputes,

If the parties do not agree to choose a settlement through conciliation / arbitration within seven working days, the manpower agency will delegate the dispute settlement to the mediator, and the settlement through the mediator becomes a settlement that must be taken (Article 4 paragraph (4) and Article 6 of Law No.2 of Year 2004). Specifically, for the settlement of disputes over rights, Law no. 2 of 2004 does not authorize the conciliator / arbitrator to arbitrate it, the authority to resolve disputes out of court is only given to the mediator [2].

Bipartite negotiations carried out by garment companies with workers 'unions (supervisors) and workers' representatives are regarding the problem of late payment of salaries and deductions in allowances, both food and transport allowances. The bipartite negotiation was the beginning of the settlement of an industrial relations dispute that occurred at the Garment company because in the end the company kept its promise to immediately pay off all arrears in salaries of its workers who were late within a certain period of time, as well as return the allowance money that had been cut due to the company's financial condition. is stable. During the negotiation activities all representative supervisors from all departments were present. Regarding the decision resulting from the bipartite negotiation, the worker obtains information from his supervisor.

\section{CONCLUSION}

Disputes between workers PT Dwi Sakti Putra entrepreneur which includes disputes over rights, disputes over interests, disputes over termination of employment, and disputes between trade unions / labor unions in only one company. The dispute was resolved through bipartite negotiations. Bipartite negotiations are the first steps taken in resolving industrial relations disputes that occur when the company negotiates with all parties. During the bipartite negotiation activity, all parties accepted the predetermined decisions. settlement of disputes that occur in accordance with legislation.

\section{REFERENCES}

[1] Chandra, Ujang, "The Model of Industrial Relations Dispute Settlement in Labor Law After the Birth of Law Number 2 of 2004," Jurnal Wawasan Yuridika, Vol. 1, No. 1, 2016.

[2] Law No. 2 of 2004 concerning Settlement of International Relations Disputes

[3] Khakim, Abdul. 2007. Introduction to Indonesian Manpower Law Revised edition. Bandung: PT Citra Aditya Bakti

[4] Law No. 13 of 2003 concerning Manpower 